\title{
Historical Perspectives of Agricultural Extension and Research- Extension-Farmers Linkage in Ethiopia
}

\section{Solomon Yokamo*}

Agricultural Technology Transfer Researcher, Arbaminch Agricultural Research Centre, Arbaminch, Ethiopia

*Corresponding Author: Solomon Yokamo, Agricultural Technology Transfer Researcher, Arbaminch Agricultural Research Centre, Arbaminch, Ethiopia.
Received: March 10, 2020

Published: April 14, 2020

(C) All rights are reserved by Solomon

Yokamo.

\section{Country profile}

- Ethiopia is a landlocked country in the Eastern parts of Africa (horn of Africa).

- It shares borders with Eritrea to the north, Djibouti to the northeast, Somalia to the east, Kenya to the south, South $\mathrm{Su}$ dan to the west and Sudan to the northwest.

- Ethiopia is the most populous landlocked country in the world and the second- most populous nation on the African continent with a total area of 1,100,000 square kilometres $(420,000 \mathrm{sq} \mathrm{mi})$ and with the population size of $>110$ million.

The nation is a land of natural contrasts, with its vast fertile west, its forests, and numerous rivers, and the world's hottest settlement of Dallol in its north.

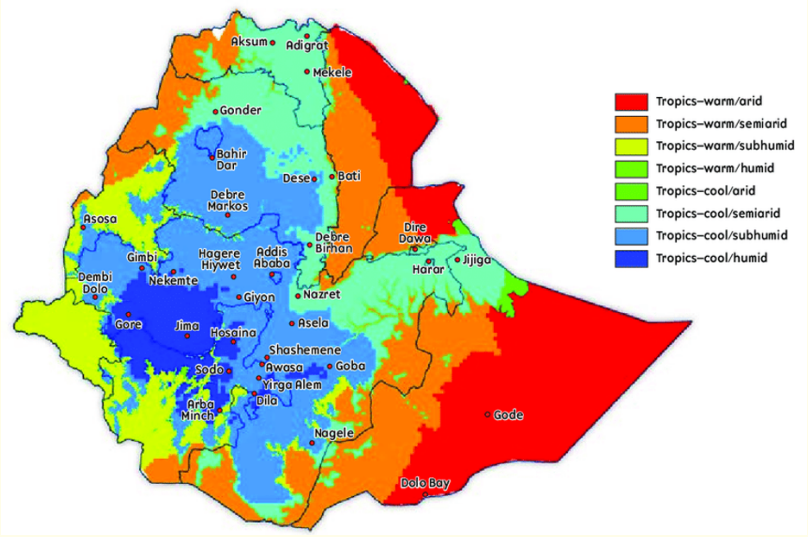

Figure 1: AEZ of Ethiopia based on Global 16 classification system.

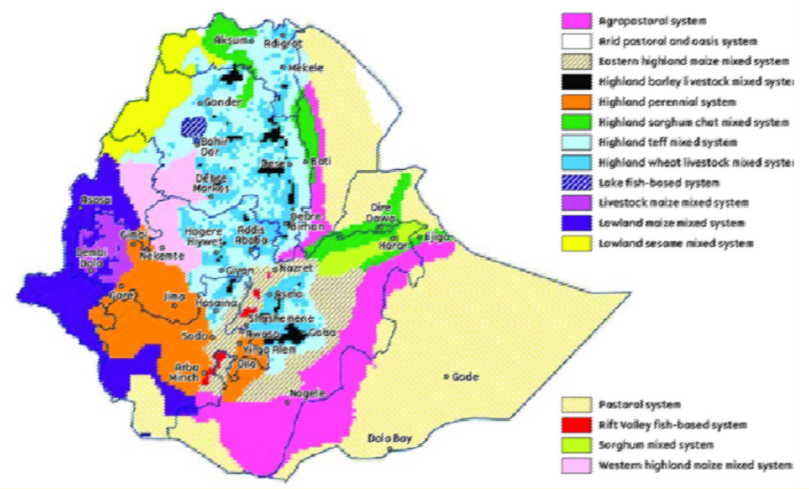

Figure 2: Ethiopian farming systems (Christopher Auricht, 2017)
Agricultural production system

- Ethiopia have a diverse geographical setup, different agroecology's and farming systems.

- Agriculture is the foundation of Ethiopian economy. Being the dominant sector, agriculture contributes about $46.3 \%$ of the total gross domestic product (GDP), $60 \%$ of exports, and $80 \%$ of total employment.

- Agricultural production is dominated by smallholder households which produce more than $90 \%$ of agricultural output.

- Smallholders drive their income either in cash or through own-consumption from agricultural production.

- According to the national accounts, the agricultural sector consists of crop, livestock, fishery and forestry sub-sectors. Crop production is the dominant sub-sector within agriculture.

There are two types of production system in Ethiopia:

1. Mixed production systems (Crop-Livestock). It accounts 70\%.

- Cereal based mixed production system.

- Cash crop based mixed farming systems.

2. Pastoral and Agro-pastoral production system. It accounts $30 \%$.

- This area are more of dry and gets low rainfall.

The major crops grown in Ethiopia

- Cereal crops such as: Maize, wheat, barley, tef, sorghum.

- Pulses: Haricot bean, chick pea, faba bean, soy bean.

- Oil crops: Sesame, sunflower, rapeseed.

- $\quad$ Spices: Garlic, cardamom, ginger, coriander.

- Fruits and Vegetables: Cabbage, head cabbage, tomato, mango, apple, Avocado, banana.

- Cash and industrial crops: Coffee, cotton.

- Roots and tuber: Enset, cassava, potato, sweet potato.

- $\quad$ Medicinal crops.

History of agricultural extension in Ethiopia

- Extension was begin in 1931 with the establishment of Ambo agricultural school. It is the first agricultural high school offering general education with a major emphasis on agriculture. 
- $\quad$ The school train students and demonstrate surrounding farmers the potential effects of improved varieties and agricultural practices.

- The school did not do extension work in the sense of the term that we understand today.

- In 1943 with the establishment of ministry of agriculture the country started little extension activity.

- $\quad$ Real extension service in Ethiopia have started in 1953 with the establishment of the Imperial Ethiopian College of Agriculture and Mechanical Arts (IECAMA), currently known as Haramaya University.

- IECAMA was mandated to have three responsibilities: teaching, research and extension.

1. The extension mandate of the college included:

- Transferring local research outputs and technologies to farmers, and

- Importing technologies and improved practices from abroad and introducing them to farmers (Ibrahim 2004).

- The extension service of the college undertook demonstrations, regular visits of individual farmer's fields and the organization of youth clubs.

1. The major extension activities were concentrated in areas where the college had experimental stations.

2. The coverage of the extension service of the college was very small compared to the needs of the country due to:

- $\quad$ Severe shortage of manpower

- Limitations in new technologies and

- Lack of complementary institutional support services such as input supply and credit service.

3. In 1963, the mandate to provide agricultural extension was moved to Ministry of Agriculture.

Agricultural extension under the imperial regime

- MoA was responsible for agriculture extension service and extension service became one of the departments in the ministry.

- Due to insufficient skilled man power and financial constraints, it was unable to modernize peasant agriculture in all areas of the country simultaneously, the government opted for the comprehensive package.

Comprehensive package approach

It involved:

- Improving the existing infrastructure

- Better and well organized social service and providing effective transportation

- $\quad$ Marketing and credit services

- $\quad$ Popularizing appropriate, well-tested and locally-adapted improved

The first comprehensive package extension program was the Chillalo Agricultural Development Unit (CADU).

Started in 1967 with financing from the Swedish International Development Agency (SIDA).
The package components included:

- Crop and livestock production

- $\quad$ Credit and marketing services

- $\quad$ Research and training

- $\quad$ Rural infrastructure development (roads, water etc.)

- Input supply (seeds and fertilizer), and home economics.

The program used demonstration plots and model farmers to train farmers organized through various field days.

Following CADU, other projects with very similar approaches were initiated:

- Wolayita Agricultural Development Unit (WADU) in 1970

- $\quad$ Ada'a Woreda Development Project (ADDP) in 1972

- $\quad$ Tach Adiyabo and Hadekti Agricultural Development Unit (TAHADU)

- Southern Region Agricultural Development Project (SORADEP) and

- Humera Agricultural Development (HAD).

Comprehensive package was not successful due to:

- It was not address vast majority of the country

- $\quad$ Failed to serve the very poor people for whom they were destined the tenants and small-scale farmers

- The principal beneficiaries were landlords and commercial farmers

- $\quad$ Comprehensive package projects were too expensive, both financially and in terms of trained manpower requirements, to warrant replication in other areas of the country.

As a result, in 1971 the government in co-operation with SIDA designed Minimum Package Project I (MPP-I).

Minimum package project-I (MPP-I)

Prepared for the 1971 - 1974 period.

Aimed to reach large number of small scale farmers with services considered to be the minimum essential elements such as:

- $\quad$ Agricultural credit, marketing and extension advice

- Dissemination of innovations such as fertilizers and highyielding hybrid seeds.

It employed an individual farmer extension approach as a method of technology transfer, where both model farmers and extension agents demonstrated the improved technologies.

\section{MPP-I failed to have a significant impact}

- No necessary reform measures in the areas of land tenure, tenant- landlord relationships and the organizational and administrative systems of the different institutions entrusted with agricultural development of the country.

- Extension activities focuses more on mixed farming system areas, very less focus to pastoral areas.

- The principal beneficiaries of the MPP-I were wealthy farmers who had access to modem inputs. 
Agricultural extension under the military regime

- $\quad$ The Derg regime, which toppled the Imperial regime in 1974, continued with the MPP-I for four years.

- $\quad$ In 1980, the Minimum Package Project II (MPP-II) was developed with funding from the World Bank, International Fund for Agricultural Development (IFAD) and SIDA.

\section{Objectives of MPP-II (1981 - 1985)}

- To improve crop and livestock productivity

- Increase the production of agricultural raw materials for domestic use and for export

- $\quad$ Soil and water conservation activity enhancement

- Establishment of farmer organizations

- Construct rural roads, grain stores and agricultural offices.

It was failed to achieve its goal due to:

- $\quad$ Less skilled man power

- Less research extension linkage

- $\quad$ Task overload for DAs including collecting loan and promoting producer cooperatives

- The poor research-extension linkage

- Lack of enough resource and capacity to develop demand driven technology

MPP-II phased out in 1985 and was replaced by a new program called Peasant Agricultural Development Program (PADEP).

Peasant Agriculture Development Extension Programme (PADEP).

Employed a modified Training and Visit (T \& V) extension system.

The program had different objectives for the different agricultural development zones. however, the principal ones were:

- Increasing food production to the level of self-sufficiency.

- $\quad$ Production of cash crops for export and raw materials for domestic industries.

- Increasing rural sector employment opportunities.

- Supporting and encouraging the development of rural cooperatives.

- $\quad$ Preventing further soil depletion.

- Introducing suitable farming system in erosion- prone areas of the country.

It also not effective due to it is not participatory, inflexible and top-down nature.

\section{Agricultural extension (Post 1991)}

- The PADEP program continued for four more years under the Ethiopian People's Revolutionary Democratic Front (EPRDF) and the $\mathrm{T} \& \mathrm{~V}$ extension approach was adopted as a national extension system.
- It was replaced by Participatory Demonstration and Training Extension System (PADETS) in 1995.

- $\quad$ PADETS became the first extension program to be developed without foreign assistance and fully funded by the government budget.

Objectives of PADETS:

- Increasing productivity and production of smallholders

- Empowering farmers to be active participants in the development process

- Increasing food self sufficiency

- Increasing the supply of raw materials for domestic use and export

- Enhancing the rehabilitation and conservation of natural resource base

- $\quad$ Encouraging farmer organizations.

PADETS classified the country into three development zones:

- Moisture reliable areas

- Moisture stress areas and

- $\quad$ Pastoral systems.

An interesting feature of PADETS is the fact that it was based on pilot extension program of the SG-2000.

NGOs have also been involved in providing extension services to farmers, mostly in more drought prone and food insecure areas

Current agricultural extension history (Post 2002)

Farmers training center (FTCs)

- Establishment of the FTCs was started in 2002 and the plan of the government is to establish about 15,000 centers throughout the country.

- $\quad$ Currently, there are close to 11,000 FTCs, of which 4,924 (or $45 \%$ ) have functional demonstration plots on which they are conducting trainings (source: ATA).

- It is a places where modular training to farmers given

- It is a demonstration sites

- It is a sources of advice on projects

- It found to be the

It provides a range of services of farmer training and extension services on improved farming techniques through:

- $\quad$ Training courses and exhibits.

- Demonstration farms, field days and farmer-to-farmer extension

- Market-oriented information and advisory services.

- Meeting and communication facilities.

- $\quad$ Seed and seedlings of new crops, vegetables, fruit and forage varieties 
It suggests the beginning of a strategic shift towards knowledge- based approach to smallholder agricultural development.

It helps to shift from a sole focus on the transfer of technology (ToT) to emphasis on human resource and social capital development.

It will contribute to rural transformation rather than being limited to agricultural development only.

It operates on the wider principle of human resources development rather than in the limited view of transfer of technologies (TOT), as has been mostly the case so far.

It is also envisioned that the DAs will not be involved in input supply and credit collection or other non-extension related activities.

The agricultural extension service at the FTCs enhances farmers linkage with other institutional support services such as input supply, credit, co-operative promotion, and agricultural produce marketing.

\section{Research-extension-farmers Linkage}

- $\quad$ Research, extension and farmers are the three main pillars of agriculture system and their effectiveness largely depends on the strong linkages among each other.

- Agricultural research without appropriate linkages with extension is like organization without plan.

- $\quad$ Agriculture research and extension (R\&E) are examples of two systems that can be linked by information flow and feedback.

- In Ethiopia, formal research and extension service was started in 1952 when the Agricultural and Technical School at Jima and the College of Agriculture and Mechanical Arts were established.

- The Institute of Agricultural Research (IAR) was established in 1966 with the mandate to formulate and implement agricultural research policy and coordinate research programs nationwide.

- The task of technology transfer was not explicitly considered part of the mandate of the research system.

- The first linkage between R\&E was the establishment of joint adaptive trials of the IAR and the Extension Program Implementation Department (EPID) of the Ministry of Agriculture (MoA) in 1974.

- The trials were initiated for technology testing and formulation of recommendations for different agro-ecological zones.

- The linkage has budgetary and organizational commitment problems.

In 1980, the linkage effort was reinitiated between the IAR and the Agricultural Development Department (ADD) of the MoA, but with the same problems.
On-farm trials were not implemented systematically to warrant meaningful results.

Researchers could not travel regularly to handle trials due to the lack of transportation and budgetary constraints.

In 1985, the IAR established a Research and Extension Division (RED) with the initiation and financial support of the World Bank. RED played an important role in:

- Disseminating research findings to subject matter specialists (SMSs) and extension agents and

- Conducting pre-extension demonstration and popularization activities.

However, it also had problems, such as inter-group relations and resource constraints.

In 1986, Research-Extension Liaison Committees (RELCs) were formed along the Peasant Agricultural Development Extension Program (PADEP) zones with a modified T\&V extension system.

The RELC have the mandate to review and approve research proposals and extension recommendations and bring $d / t$ stakeholders together to make the linkage effective.

RELCs were not successful:

- Meetings were irregular.

- It lacked decision making power to enforce linkage activities.

- There is no accountability and incentive system.

In 1999, the research-extension linkage issue revived with a new linkage strategy Research-Extension-Farmers Advisory Councils (REFACs) [1] at federal, regional and zonal levels to bring together stakeholders in the entire process of technology generation, transfer, utilization and feedback.

The federal advisory council was the highest responsible body for the overall policy guidelines and oversight with regard to research and extension program co-ordination and linkage activities in the country.

REFACs at the zonal level contributed to the establishment of farmer research groups (FRGs).

It also didn't met its target due to different challenges.

In 2008, under the leadership of the MoA, Agriculture Development Partners Linkage Advisory Councils (ADPLACs) have been established at different levels to promote alignment and collaboration among the major stakeholders in the agricultural sector.

The ADPLAC, as a multi-stakeholder platform:

- National platform

- Regional platform

- Zonal and

- $\quad$ District level platforms 
The MoA acts as a central coordinating body that facilitates linkages \& communications across the different levels.

\section{Key functions of the ADPLACs:}

- $\quad$ Creating stakeholder alignment on development policies and agendas

- Identification and prioritization of scalable development interventions and practices

- Monitoring and accountability mechanism

- $\quad$ Sharing experiences among major stakeholders across regions and sectors.

The performance of ADPLACs can be evaluated based on:

- $\quad$ Composition of membership

- $\quad$ Periodicity and quality of meetings

- $\quad$ Outcomes of the meetings

ADPLAC is organized to

- $\quad$ Strengthen FTCs through active participation of community and capacity building

- Enhancing agricultural knowledge and information services

- $\quad$ Facilitating market linkage, gender, youth, and nutrition mainstreaming

- $\quad$ Strengthening environmentally sustainable agricultural practices

- Developing human resource and institutional arrangements

- $\quad$ Creating linkages among key agricultural development partners

- Enhance client oriented and multi actor's advisory extension services

- Establishing strong and dynamic result-based monitoring, evaluation, and learning.

Challenges with ADPLAC

- Weak stakeholder coordination and engagement capacity at all levels

- $\quad$ Frequent reshuffling of institutional representatives

- $\quad$ Commitment problems

- $\quad$ Limited linkage with ATVET

- $\quad$ Limited awareness at district level

Results from a survey among ADPLAC stakeholders in the Amhara region [2] shows that, only $45 \%$ respondents aware about the ADPLAC existence [3-10].

\section{To make the platform strong:}

- $\quad$ Efficient monitoring, learning and evaluation mechanism will be needed

- Manageable, relevant and influential inclusive membership

- $\quad$ Sharing and tracking role and responsibility

- $\quad$ Solving logistic constraints.
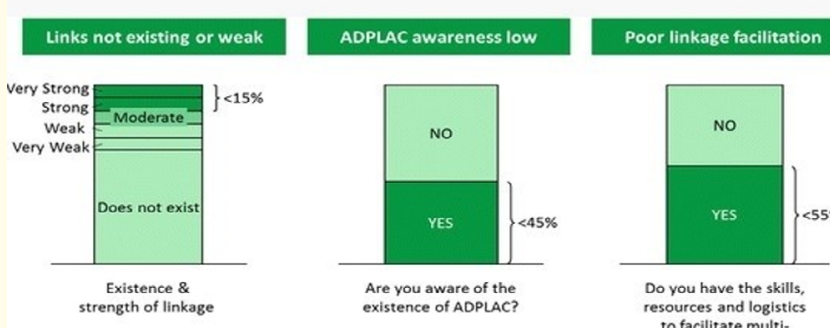

Figure 3

\section{Bibliography}

1. FDRE (The Federal Democratic Republic of Ethiopia). Agricultural Research and Training Project: Ethiopian ResearchExtension- Farmer Linkages Strategy, volume I, Addis Ababa (1999).

2. Demekech Gera., et al. "Multi-stakeholder linkages in rural innovation processes in the Amhara region". Working Document Series 137. ICAR, Bahir Dar University and ARARI (2010).

3. Alemu D and Demese C. "The National Extension Intervention Program (NIEP) and sustainable agricultural development" (2005).

4. Amede T., et al. "A farming system framework for investment planning and priority setting in Ethiopia". ACIAR Technical Reports Series No. 90 (2017).

5. Ashworth V. "The challenges of change for agricultural extension in Ethiopia: A discussion paper". Federal Democratic Republic of Ethiopia, Addis Ababa, Ethiopia (2005).

6. Belay Kassa. "Agricultural extension in Ethiopia: the case of participatory demonstration and training extension System". Journal of Social Development in Africa 18.1 (2003).

7. Ethiopian Agricultural Research Organization (EARO). "Research Extension Linkage Strategy". EARO, Addis Ababa (2000).

8. Goshu M. "Agricultural Research and Extension in Ethiopia: An Overview". In: Dejene, A. and Mulat, D. (Eds.), Ethiopian Agriculture: Problems of Transformation, Proceedings of the $4^{\text {th }}$ Annual Conference on the Ethiopian Economy, Addis Ababa: Agricultural Economics Society of Ethiopia (1995): 373-390.

9. Institute of Agricultural Research (IAR). Briefing Note on the IAR. IAR Addis Ababa (1989).

10. Teklu T. "Research-Extension-Farmer Linkages: A Conceptual framework to Strengthen partnership among stakeholders". EIAR, Ethiopia (2001) 
Assets from publication with us

- Prompt Acknowledgement after receiving the article

- Thorough Double blinded peer review

- Rapid Publication

- Issue of Publication Certificate

- High visibility of your Published work

Website: www.actascientific.com/

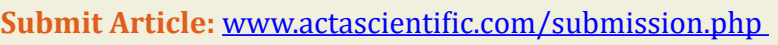

Email us: editor@actascientific.com

Contact us: +919182824667 